\title{
IMPACT OF BUYER'S LENIENT POLICY OF RETURN AND TRUST ON INTERNET PURCHASE DECISION IN SUPPLY CHAIN SECTOR OF PAKISTAN
}

\author{
Muhammad Ammad Ansari \\ MBA in Supply Chain Management \\ Karachi University Business School \\ University of Karachi, Pakistan \\ E-mail: ammadraees@gmail.com \\ Dr. Sohaib Uz Zaman \\ Assistant Professor \\ Karachi University Business School \\ University of Karachi, Pakistan \\ E-mail: sohaibuzzaman@uok.edu.pk
}

\begin{abstract}
This article aims to investigate the factors that impact the internet purchase decision in supply chain sector of Pakistan because our mode of purchasing has been changed dramatically as a result of the Internet. An increasing number of individuals prefer online mode of shopping rather than in physical stores. Despite of these benefits there possess some cons of online purchasing like complicated returns, difficult websites, no sales assistance and lack of trust. In this article, impact of two independent variable i.e., lenient policy of return of buyer and trust of buyer was analyzed against the dependent variable internet decision of purchase. A questionnaire of 21 questions was prepared. Data of 100 respondents was collected from buyers of Karachi. Reliability Analysis, ANOVA and regression analysis are performed using SPSS tool to find the results. Study concluded that lenient policy of return of buyer and trust of buyer has positive association with internet decision of purchase in Pakistan which means when buyers are provided with lenient policies for the return of goods for any reason and their trust in seller increases it will impact the decision of purchase positively. Thus, it will be beneficial in terms of chasing market competition and generating higher returns.
\end{abstract}

Keywords: Lenient Policy of Returns, Customer Trust, Internet Purchase Decision, Regression Analysis, Supply Chain Sector, Pakistan.

\section{INTRODUCTION}

The Internet is a significant piece of every day and week by week exercises of people approaching it. It is an entryway to the universe of information. Internet buying and selling has gained a significant growth in Pakistan as well. Store's merchandise exchange was a significant factor in a buying choice. In this way, having a thoroughly examined merchandise exchange policy showed in your store is a critical way to keep your clients. A merchandise exchange is acceptable business for physical stores, and it's fundamental to working together on the web too. 
In contrast to physical stores, online shoppers don't see and hold the actual item before they get it. So, the online business dealers should guarantee that merchandise exchanges are reasonable and interesting to their clients. A brief and clear merchandise exchange gives shoppers a sense of safety that what they are purchasing is destined to be what it is addressed to be. Assuming a retailer doesn't give this assurance; shoppers frequently become dubious and try not to purchase the item. Many merchandise exchanges have restrictive arrangements which may become barrier in internet decision of purchase.

Client trust is a proportional conduct to what they get. Trust comes when you comprehend your client's necessities, regard them, and proposition important assistance. Acquiring client's trust is significant not exclusively to make them faithful and return, yet in addition so they demand their companions work with you as well. Trust is an administration system seeing someone concerning trades. It is portrayed by vulnerability, weakness or reliance Grazioli and Jarvenpaa (2003). In early explores, scarcely any variables have been perceived to impact internet shopping practices with the assistance of brought together buyer situated exploration model. The significant forerunners to online shopper conduct were taken to be earlier web-based shopping experience and trust. Grazioli and Jarvenpaa (2003) upheld that client don't take part in web-based shopping because of absence of trust.

A customer's propensity to acquire a certain product or service is referred to as purchase intention. Purchase intentions are a measure of a respondent's willingness to buy something or use a service. The factors studied in this research are lenient policy of return of buyer and trust of buyer with internet decision of purchase.

\section{LITERATURE REVIEW}

The impact of lenient return policies on product purchase decisions and subsequent returns is investigated in the study by Petersen and Kumar (2010). He discovered that lenient return policies are linked to greater purchase and also greater return rates.

Lenient return policies, according to Wood (2001) and Wang (2009), boost purchasing without increasing returns. When compared to the restricted return policy, the lenient return policy increased buying but did not result in higher return rates as per Wood (2001). Similar results were reported by Wang (2009), who discovered that lenient return policies boosted initial purchase decision but not return rate.

Janakiraman et al. (2015) discover that return leniency has a direct beneficial impact on purchase and return behaviors. The mediating processes that explain how returns interpret to purchase intentions, however, are less well understood, according to their meta-analysis.

A clear and acceptable return policy, according to Rogers and Tibben-Lemke (2001), is one of the most essential instruments for attracting consumers. Consumers who have made purchases from an online vendor in the presence of a product return (returned experienced customers), according to Qureshi et al. (2009), would repurchase from such vendors.

When it comes to internet shopping, trust is crucial. Consumers cannot personally verify the goods, which lead to trust difficulties in internet purchases. Consumer trust increases online purchasing decisions significantly accordingly Mahliza, Febrina. (2020).

\section{PROBLEM STATEMENT}

As per the preceding literature available it is clear that return policy and customer trust are severe points of concerns for seller. Due to great competition, it is very difficult to retain customer which can be only possible by providing beneficial service like good return policy so this will 
simultaneously develop customer trust in us. This will lead to greater return and customer will come again for repurchase.

\section{RESEARCH OBJECTIVE}

Research objective is to find if there is positive association among of lenient policy of return of buyer and trust of buyer with internet decision of purchase in supply chain sector of Pakistan

\section{SIGNIFICANCE OF STUDY}

This study is essential for the internet purchasing supply chain sector as a whole in order to examine supply chain policy of return dimensions i.e., supply chain return risks derived disruption factor which allows company get stick to one seller. As the internet purchasing supply chain sector as a whole is related to high frequency risk of return dimensions due to the high uncertainty in internet purchasing supply chain environment Therefore, examine trust of buyer mediates positive association among of lenient policy of return of buyer and perceived seller quality with internet decision of purchase in supply chain sector of Pakistan.

\section{RESEARCH METHODOLOGY}

\section{Conceptual frame work}

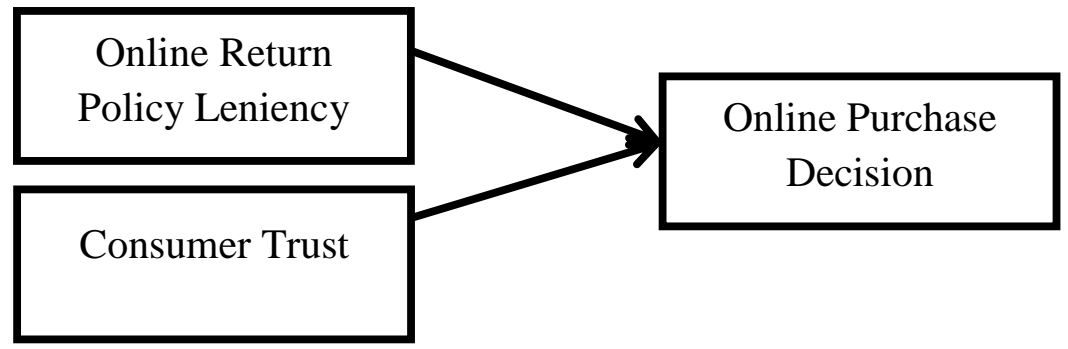

\section{Research Approach}

Explanatory research type is used for this research to examine positive association among of lenient policy of return of buyer and trust of buyer with internet decision of purchase in internet purchasing supply chain sector of Pakistan. We have used quantitative research approach to find the association among the dependent and independent variable. Data collected was changed in to numbers to quantified and tested empirically.

\section{Sample Size and Population}

The sample size, selected for this study is 100 . For this study the target population is internet shopper and buyers exist in Karachi so it was not difficult to obtain data.

\section{Statistical Techniques}

This research used the SPSS software and according to research it is appropriate to run reliability analysis, ANOVA and regression analysis.

\section{Questionnaire and Measurement Instrument}

There are 21 items selected in preparing questionnaire for the dependent and independent variables i.e., lenient policy of return of buyer, trust of buyer, and internet decision of purchase. 
Each, the variables carried 7 items and is adopted to examine the impact of lenient policy of return of buyer and trust of buyer on the internet decision of purchase.

\section{Hypothesis}

H1: There is positive association between lenient policy of return of buyer and internet decision of purchase.

H2: There is positive association between trust of buyer and internet decision of purchase.

\section{DATA ANALYSIS AND INTERPRETATION}

\section{Demographics}

Gender

\begin{tabular}{|ll|l|l|l|l|}
\hline & & Frequency & Percent & Valid Percent & Cumulative Percent \\
\hline \multirow{3}{*}{ Valid } & Male & 61 & 61.0 & 61.0 & 61.0 \\
& Female & 39 & 39.0 & 39.0 & 100.0 \\
& Total & 100 & 100.0 & 100.0 & \\
\hline
\end{tabular}

It is to be observed out of 100,61 participants were male which extracted the $61 \%$ of the data and there were 39 female participants which extracted the $39 \%$ of the data collected.

\begin{tabular}{|ll|l|l|l|l|}
\hline \multicolumn{6}{|c|}{ Age } \\
\hline \multirow{6}{*}{ Valid } & Frequency & Percent & Valid Percent & Cumulative Percent \\
& $20-25$ yrs & 44 & 44.0 & 44.0 & 44.0 \\
26-30 yrs & 32 & 32.0 & 32.0 & 76.0 \\
& $31-35$ yrs & 15 & 15.0 & 15.0 & 91.0 \\
& $36-40$ years & 5 & 5.0 & 5.0 & 96.0 \\
& Over 50 & 4 & 4.0 & 4.0 & 100.0 \\
Total & 100 & 100.0 & 100.0 & \\
\hline
\end{tabular}

Among 100 participants 44 number of participants which extracts $44.0 \%$ are belong to the age group of 20-25 years, 32 number of participants which extracts $32 \%$ are belong to the age group of 26-30 years, 15 number of participants which extracts $15 \%$ are belong to the age group of 3135 years, 5 number of participants which extracts 5\% are belong to the age group of 36-40 years, 4 number of participants which extracts $4 \%$ are belong to the age group of Over 50 years.

Education

\begin{tabular}{|cl|l|l|l|l|}
\hline & & Frequency & Percent & Valid Percent & Cumulative Percent \\
\hline \multirow{6}{*}{ Valid } & Matric & 9 & 9.0 & 9.0 & 9.0 \\
& Intermediate & 17 & 17.0 & 17.0 & 26.0 \\
& Bachelors & 38 & 38.0 & 38.0 & 64.0 \\
& Masters & 35 & 35.0 & 35.0 & 99.0 \\
& Other & 1 & 1.0 & 1.0 & 100.0 \\
Total & 100 & 100.0 & 100.0 & \\
\hline
\end{tabular}


Out of 100 participants $9(9.0 \%)$ of the participants are Metric, $17(17.0 \%)$ of the participants are Intermediate, $38(38.0 \%)$ of the participants are Bachelors, $35(35.0 \%)$ of the participants are Masters, $1(1.0 \%)$ of the participants are others.

\section{Marital Status}

\begin{tabular}{|ll|l|l|l|l|}
\hline & & Frequency & Percent & Valid Percent & Cumulative Percent \\
\hline \multirow{4}{*}{ Valid } & Married & 34 & 34.0 & 34.0 & 34.0 \\
& Unmarried & 66 & 66.0 & 66.0 & 100.0 \\
& Total & 100 & 100.0 & 100.0 & \\
\hline
\end{tabular}

Out of 100 participants $34(34.0 \%)$ of the participants are married, $66(66 \%)$ of the participants are unmarried.

Reliability Analysis

\begin{tabular}{llll} 
& Variable & Cronbach's Alpha & No. of items \\
\hline ORPL & Internet Policy of return Leniency & 0.891 & 07 \\
CT & Trust of buyer & 0.915 & 07 \\
OPD & Internet Decision of purchase & 0.945 & 07 \\
\hline & Over all & 0.968 & 21 \\
\hline
\end{tabular}

The reliability of data obtained is checked through Cronbach's alpha test. Acceptable range for Cronbach's alpha is $\alpha$ of $\mathbf{0 . 6 - 0 . 7}$ indicates an acceptable level of reliability. The values for reliability test obtained are greater than 0.7. For Internet Policy of return Leniency value is 0.891 , for trust of buyer is 0.915 and for Internet Decision of purchase is 0.945

\section{Model Summary}

\begin{tabular}{|c|c|c|c|c|c|c|c|c|c|c|}
\hline \multirow[t]{2}{*}{ Model } & & \multirow{2}{*}{$\begin{array}{l}\mathrm{R} \\
\text { Square }\end{array}$} & \multirow{2}{*}{$\begin{array}{l}\text { Adjusted } \\
\text { R Square }\end{array}$} & \multirow{2}{*}{$\begin{array}{l}\text { Std. Error } \\
\text { of the } \\
\text { Estimate }\end{array}$} & \multicolumn{5}{|c|}{ Change Statistics } & \multirow{2}{*}{$\begin{array}{l}\text { Durbin- } \\
\text { Watson }\end{array}$} \\
\hline & & & & & $\begin{array}{l}\text { R Square } \\
\text { Change }\end{array}$ & \begin{tabular}{|l|} 
F \\
Change
\end{tabular} & df1 & df2 & $\mid \begin{array}{l}\text { Sig. F } \\
\text { Change }\end{array}$ & \\
\hline 1 & $.874^{\mathrm{a}}$ & .764 & .759 & .46465 & .764 & 156.582 & & 97 & .000 & 1.980 \\
\hline
\end{tabular}

a. Predictors: (Constant), CT, ORPL

b. Dependent Variable: OPD

Table shows that the Independent Variables online return policy leniency and customer trust explain $76.4 \%$ of variance in the online purchase decision as represented by $\mathrm{R}$ square.

\section{ANOVA}

\begin{tabular}{|ll|l|l|l|l|l|}
\hline Model & & Sum of Squares & df & Mean Square & F & Sig. \\
\hline \multirow{4}{*}{1} & Regression & 67.613 & 2 & 33.807 & 156.582 & $.000^{\mathrm{b}}$ \\
& Residual & 20.943 & 97 & .216 & & \\
& Total & 88.556 & 99 & & & \\
\hline
\end{tabular}


a. Dependent Variable: OPD

b. Predictors: (Constant), CT, ORPL

Table shows that our model is significant at $\alpha=.05, \mathrm{~F}(2,97)=156.582$ and $\mathrm{p}=.000$ which is less than .05

\section{Coefficient table}

\begin{tabular}{|c|c|c|c|c|c|c|c|c|c|c|}
\hline \multirow[t]{2}{*}{ Model } & \multicolumn{2}{|c|}{$\begin{array}{l}\text { Unstandardized } \\
\text { Coefficients }\end{array}$} & \multirow{2}{*}{\begin{tabular}{|l} 
Standardized \\
Coefficients
\end{tabular}} & & \multirow[t]{2}{*}{ Sig. } & \multicolumn{5}{|c|}{$\begin{array}{l}\text { 95.0\% Confidence } \\
\text { Interval for B }\end{array}$} \\
\hline & $B$ & $\begin{array}{l}\text { Std. } \\
\text { Error }\end{array}$ & & & & $\begin{array}{l}\text { Lower } \\
\text { Bound }\end{array}$ & $\begin{array}{l}\text { Upper } \\
\text { Bound }\end{array}$ & $\begin{array}{l}\text { Zero- } \\
\text { order }\end{array}$ & Partial & Part \\
\hline (Constant) & .255 & .186 & & 1.372 & .173 & -.114 & .624 & & & \\
\hline ORPL & .457 & .106 & .426 & 4.317 & .000 & .247 & .667 & .840 & .401 & .213 \\
\hline CT & .507 & .104 & .479 & 4.861 & .000 & .300 & .713 & .847 & .443 & .240 \\
\hline
\end{tabular}

a. Dependent Variable: OPD

The table shows that all the predicators are significantly correlated with dependent variable. Online return policy leniency is 0.457 that shows significantly positive impact as $(\mathrm{sig}>0.05)$ on internet decision of purchase. Secondly, customer trust is 0.507 that shows significantly positive impact as ( $\mathrm{sig}>0.05)$ on online purchase decision.

\section{Regression model:}

The regression equation obtained is:

$$
\begin{gathered}
\mathrm{Y}=\beta \mathrm{o}+\beta_{1} \mathrm{x}_{1}+\beta_{2} \mathrm{X}_{2}+\epsilon \\
\mathrm{Y}=0.255+0.457 \mathrm{x}_{1}+0.507 \mathrm{x}_{2}
\end{gathered}
$$

Where

$\mathrm{Y}=$ Dependent Variable online purchase decision OPD

$\beta o=$ intercept

$\beta_{1}$ and $\beta_{2}=$ slope

$\mathrm{X}_{1}$ and $\mathrm{X}_{4}=$ Independent Variables online return policy leniency ORPL and customer trust CT

$\epsilon=$ Residual or error term

\section{CONCLUSION}

Conclusively, this research categorically confirmed the impact of the purchasing by internet retailer antecedents i.e., internet policy of return leniency and trust of buyer on internet decision of purchase. Evidently, the Pakistani purchasing by internet sector in order to investigate antecedents i.e., internet policy of return leniency, trust of buyer on internet decision of purchase factors, which allows buyers get stick to one internet retailing website. As the purchasing by internet sector business interested in high frequency purchasing by internet retailer antecedents due to the high competition. Therefore, this research investigates the impact by internet website's policy of return antecedents in the context of Pakistan, which is valid and practically proved. 
Where, threats of new entrant are increasing day by day. Already there is huge competition exist in this sector which getting worse competition for the sake of acquiring maximum buyer i.e., market share in this website retailing domain towards Pakistani purchasing by internet sector. For the sake of market share and new buyer attraction and increasing retention buyer rate it is necessary to provide best policy of return in the sector for respective buyer and then attaining trust of buyer which will lead to attract buyer to purchase again and generate higher returns.

\begin{tabular}{ll}
\hline Hypothesis & $\begin{array}{l}\text { Accepted Or } \\
\text { Rejected }\end{array}$ \\
\hline H1: There is positive association between lenient policy of return of buyer & Accepted \\
$\begin{array}{l}\text { and internet decision of purchase. } \\
\text { H2: There is positive association between trust of buyer and internet } \\
\text { decision of purchase }\end{array}$ & Accepted \\
\hline
\end{tabular}

\section{FUTURE RECOMMENDATION}

Future research can be on role of third-party ICT policy of return dimensions i.e., internet policy of return leniency, trust of buyer-on-buyer policy of return with significant mediating effect of buyer satisfaction with provided policy of return in local courier sector of Pakistan. Secondly, research can be on effect of intermediary's policy of return factors i.e., speed, responsiveness and timelines policy of return on retailer policy of return with significant mediating effect of retailer satisfaction with provided policy of return in local retailing sector of Pakistan. Lastly, research can be on impact of third vendor managed inventory policy of return on buyer loyalty with significant mediating effect of buyer satisfaction in local restaurants sector of Pakistan.

\section{REFERENCES}

Fang, Yulin \& Qureshi, Israr \& Ramsey, E. \& Mccole, Patrick \& Compeau, Debbie \& Ibbotson, Patrick. (2009). Understanding Online Customer Repurchasing Intention and the Mediating Role of Trust - An Empirical Investigation in Two Developed Countries. Elaine Ramsey. 18. 10.1057/ejis.2009.15.

Grazioli, Stefano \& Jarvenpaa, Sirkka. (2003). Consumer and Business Deception on the Internet: Content Analysis of Documentary Evidence. International Journal of Electronic Commerce. 7. 93-118.

Janakiraman, Narayan \& Syrdal, Holly \& Freling, Ryan. (2015). The Effect of Return Policy Leniency on Consumer Purchase and Return Decisions: A Meta-analytic Review. Journal of Retailing. 10.1016/j.jretai.2015.11.002.

Kumar, V. \& Petersen, J. \& Leone, Robert. (2010). Driving Profitability by Encouraging Customer Referrals: Who, When, and How. Journal of Marketing - J MARKETING. 74. 117. 10.1509/jmkg.74.5.1.

Mahliza, Febrina. (2020). Exploring Trust in Purchase Intention: An Empirical Research on Agricultural Application. 10.2991/aebmr.k.200205.015. 
Rogers, Dale \& Lembke, Ronald. (2001). An Examination of Reverse Logistics Practices. Journal of Business Logistics. 22. 129 - 148. 10.1002/j.2158-1592.2001.tb00007.x.

Wang, Xianghong. (2009). Retail Return Policy, Endowment Effect, and Consumption Propensity: An Experimental Study. The B.E. Journal of Economic Analysis \& Policy. 9. 38-38. 10.2202/1935-1682.2288.

Wood, Stacy. (2001). Remote Purchase Environments: The Influence of Return Policy Leniency on Two-Stage Decision Processes. Journal of Marketing Research - J MARKET RESCHICAGO. 38. 157-169. 10.1509/jmkr.38.2.157.18847.

\section{Copyrights}

Copyright for this article is retained by the author(s), with first publication rights granted to the journal. This is an open-access article distributed under the terms and conditions of the Creative Commons Attribution license (https://creativecommons.org/licenses/by/4.0) 